\title{
RELATIONSHIP BETWEEN PHYTOPLANKTON, ZOOPLANKTON AND FISH CULTURE IN A FRESHWATER FISH FARM
}

\author{
Adel A. Mageed and Adel H. Konsowa \\ Nat. Inst. Ocean. Fish., 101 Kasr Al Ainy St., Cairo, Egypt
}

Keywords: Fish culture, Oreochromis niloticus, fertilization, physicochemical parameters, phytoplankton, zooplankton, trace metals, fish predation.

\begin{abstract}
This study was carried out at the Barrage Fish Farm during 2001 1 farming season. It was performed to evaluate the plankton communities and the effect of fish ponds on their standing crop and species composition.

The data revealed that the phytoplankton communities are represented by five classes namely Chlorophyceae,Bacillariophyceae, Cyanophyceae, Dinophyceae and Euglenophyceae. Their major peak was observed at Pond 6 while the minor one was found at Pond 5 . With regard to the monthly variations, phytoplankton communities flourished in July while their minimum occurrence occurred in September and August. The zooplankton species belonged to rotifers, cladocerans, and copepods in addition to the meroplanktonic forms. Rotifers were most common in all ponds. It constituted $94.64 \%$ of total zooplankton in the ponds. Copepoda occupied the second predominant position and contributed $4.23 \%$ of total zooplankton crop. Cladocera was dominated by Moina micrura. The average zooplankton number at the ponds was $258.4 \mathrm{org} \mathrm{l} \mathrm{l}^{-1}$, their major peak of 1073 org. $1^{-1}$ was observed at Pond 3 in April, while the minor one of 20 org. $1^{-1}$ occurred at Pond 5.

Fish culture had obviously influenced the intraplanktonic dynamics. Chlorophyceae occupied the first predominant position at the fishponds and constituted about $60 \%$ of the total crop followed by Bacillariophyceae $(25.8 \%)$ and Cyanophyceae (14\%). Diatoms replaced green algal position at the River Nile water and contributed about $70 \%$ of the total numerical density. The small rotifers and nauplius larvae of copepods were the most dominant in fishponds in spite of the large forms in the main feeder.
\end{abstract}


Trace metal contents recorded at the sediment of fish ponds were much higher than the corresponding values determined at the River Nile (main feeder). Iron concentrations were substantially higher at the edible muscle tissues of fishes caught from the fish farm compared to River Nile specimens. Its contents were much higher in comparison with $\mathrm{Mn}$ and Ni levels.

\section{INTRODUCTION}

Predation by fish determines the abundance of herbivorous zooplankton, which in turn regulates the level of phytoplankton (Carpenter et al.1985). A recent study (Sarvala et al.1998) revealed that changes in the abundance of planktivorous fish do affect both the phytoplankton and zooplanktoin. However, most of the avalabile information comes from experimental enclosures and much less is known about trophic interactins in large ponds (Brett and Goldman, 1996). Exploitation of fisheries resources in Egypt, as well as elsewhere in Africa, has been carried out in the absence of adequate ecological knowledge of the fish food organisms (Mavuti, 1990. The high percentage of the global fish species found in fresh water and the ability of some species to produce very high fish yields indicate that natural feeding strategies used by freshwater fishes are highly successful (Fernando, 1994). Understanding these strategies will assist in fish culture and management of freshwater fisheries. In the recent years, attention has been turned toward fish farming for increasing fish yield. The Nile tilapia are considered the most important fish species in Egypt. It occupied more than $70 \%$ of the Egyptian fish landing (Ishak et al. 1985). Planktivorous fish have a major influence on the structure of the whole plankton where they modify the density and size structure of communities (Carpenter $e t$ al.1985).

Phytoplankton and zooplankton are considered the main natural food for fish culture especially during the early stages. Semour (1980) stated that the carrying capacity and production of fishponds could be increased by fertilization that encourages growth of phytoplankton and in turn zooplankton that is required as natural food for fish. Touliabah (1992) evaluated the impacts of fish production and fertilization on managing phytoplankton in Serw Fish Farm. Shehata et al. (1994) conducted two experiments for six months in the barrage fish farm to determine the optimum fertilizer doses (urea and super-phosphate) which increase phytoplankton and 


\section{RELATIONSHIP BETWEEN PHYTOPLANKTON, ZOOPLANKTON AND FISH CULTURE IN A FRESHWATER FISH FARM}

zooplankton populations for tilapia culture in addition to the artificial food. Sweilum (2001) studied the culture of Oreochromis niloticus in mono-, di-, and poly-culture systems in the Barrage fish farm during the season of study. He reported that the highest growth rate of Nile tilapia was in polyculture system than the mono- and di-culture

The relationship between phytoplankton, zooplankton and fish culture is of paramount importance in determining the water quality on one hand and the natural productivity and the fish production on the other. This point hadn't been studied before in the farm. The aim of the present study is to determine these relations in the Barrage fish farm as a freshwater fish farm.

\section{MATERIAL AND METHODS}

This study was carried out at the freshwater fish farm of Fish Culture Research Station at El Kanater El Khyria, about $30 \mathrm{~km}$ north of Cairo. Fishes (Oreochromis niloticus, Sarotherodon galilaews, and Clarias gariepinus) were distributed at three different combinations of mono-, di-, and polyculture systems, stocked on 8 April 2000 and harvested in 14 November 2000.

The farm includes seven earthen ponds supported by calcareous stones from sides with a water level of about $1 \mathrm{~m}$ (Table 1). River Nile water via Menofi Branch is the main feeder of the fish farm (MF). The fresh water discharges to the ponds through feeder canal (F1) and the drainage water inflow to another one (F2).

Sampling was carried out on monthly basis from the two banks of each pond. Water temperature and $\mathrm{pH}$ were measured in ponds by portable $\mathrm{pH}$ - meter (Jenway 3250). The nutrient salts were measured colorimetrically using Spectronic $20 \mathrm{D}$ and expressed as $\mu \mathrm{g}$ $\mathrm{I}^{-1}$. Nitrite- $\mathrm{N}$ was determined according to Bornes and Follcard (1975), nitrate- $\mathrm{N}$ was measured using cadmium column technique according to Nydahi (1976), ammonium- $\mathrm{N}$ was measured as reported by Booth and Lobring (1973) and phosphate-P was determined as described by Strickland and Parsons (1965).

Fish species for metal analysis were selected so that a range of size was available for each species. In the laboratory, specimens were rinsed in distilled water and fillets removed from both sides. The fish samples were frozen and kept at $-20^{\circ} \mathrm{C}$ prior to analysis. The dry homogenized samples were digested for 3 hours with concentrated 
nitric acid (Hornung \& Kress, 1991). The samples of sediment were collected, digested and analyzed according to the standered techniques as reported in Messiha-Hanna (1992). The concentrations of $\mathrm{Fe}, \mathrm{Ni}$, and $\mathrm{Min}$ were measured by Atomic Absorption (Perkin Elmer-Model 3110) according to APHA et al. (1992). The data were discussed in terms of $\mu \mathrm{g} \mathrm{g}^{-1}$ wet wt.

For preparation and examination of phytoplankton the water samples were preserved in situ with Lugol's Iodine solution. A known volume of the samples was allowed to stand on a graded cylinder for five days untill the algal species had settled and then siphoned off the supernatant with plastic tube ended with plankton cloth of 5 um mesh diameter. A drop method was applied for counting and identification of different phytoplankton species. Examination of diatoms requried drying a few drops of the concentrated samples in coverglass for 20 minutes on a hot plate. This treatment drives off most of the organic matter present leaving only siliceous diatom cells wall. If the organic matter was not completely removed, the material was boilied in about ten times its volume of commercial hydrochloric acid for 20 minutes, then commercial nitric acid was then added to the boiling solution to bring about the rapid oxidation of the organic matter. The samples was then rinsed with distilled water. The main references used for identification of phytoplankton organisms were: Weber (1971), Kimor \& Pollingher (1965), Vinyard (1975), Stansbery (1971) and Dillard (1989).

Standing crop and species composition of zooplankton were determined by filtration of 20 litres from two banks of each pond, through a $55 \mu$ mesh net and fixed with a final concentration $4 \%$ neutral formaline ... The following references were used for identification of zooplankton species: Yamamato (1960), Edmandson (1966), Ruttner-Kolisko (1974), Pennak (1978) and Verheye \& Dumont (1984). The mean values of organisms were estimated for each sample and expressed as a number of organisms/liter.

Correlation coefficient was done by Microsoft Excel Program $5.0 / 7.0(1997)$.

\section{RESULTS}

\section{Physico-chemical parameters:}

The average values of the measured physicochemical parameters are presented in Table (2). Regional average value of water temperature varied within a narrow range. Its values varied 


\section{RELATIONSHIP BETWEEN PHYTOPLANKTON, \\ ZOOPLANKTON AND FISH CULTURE IN A FRESHWATER FISH FARM}

FISH EARM

from $28.3^{\circ} \mathrm{C}$ at Pond 7 to $31.48^{\circ} \mathrm{C}$ at Pond 1 . Its monthly variations showed that, the minimum temperature $23.4^{\circ} \mathrm{C}$ was recorded in October while the maximum temperature of $37.2^{\circ} \mathrm{C}$ occurred in August.

The regional average $\mathrm{pH}$ values ranged from 7.61 at Pond 5 to 8.03 at Pond 6 . The monthly $\mathrm{pH}$ values showed a sharp decline in July (6.88), while its maximum value of 8.33 was recorded in April.

The present data of nutrients reveaied that, $\mathrm{NH}_{4}-\mathrm{N}$ levels at the Ponds were much higher than $\mathrm{NO}_{2}-\mathrm{N}$ and $\mathrm{NO}_{3}-\mathrm{N}$ concentrations. $\mathrm{NO}_{2}-\mathrm{N}$ values ranged from $6.18 \mu \mathrm{g} \mathrm{l}^{-1}$ at Pond 4 to $25.34 \mu \mathrm{g} \mathrm{l}^{-1}$ at Pond 1. Its monthly concentrations varied between $6.8 \mu \mathrm{g} \mathrm{l}^{-1}$ in October and $21.01 \mu \mathrm{g}^{-1}$ in August. $\mathrm{NO}_{3}-\mathrm{N}$ contents increased from $60.8 \mu \mathrm{g} \mathrm{l} \mathrm{I}^{-1}$ at Pond 6 to $219.2 \mu \mathrm{g} \mathrm{l^{-1 }}$ at Pond 3. Its monthly variations revealed an obvious increase in April when the highest value of 187.2 $\mu \mathrm{g} \mathrm{I}^{-1}$ was observed. On the other hand, $\mathrm{NO}_{3}-\mathrm{N}$ reached its lowest concentrations of $57.6 \mu \mathrm{g} \mathrm{l}^{-1}$ in August and October. $\mathrm{NH}_{4}-\mathrm{N}$ levels revealed a wide fluctuation, where its minimum value being $179.5 \mu \mathrm{g}$ $I^{-1}$ at Pond 7, while its maximum concentration was $717.4 \mu \mathrm{g}^{-1}$ at Pond 5. Its monthly variations showed a distinct increase in April and July (420.3 $\mathrm{Mg} \mathrm{l}^{-1}$ and $450.67 \mu \mathrm{g} \mathrm{l}^{-4}$ ), while the minimum value of $124.44 \mu \mathrm{g} \mathrm{l}^{-1}$ was observed in August.

$\mathrm{PO}_{4}-\mathrm{P}$ levels recorded at fishponds showed a remarkable increase compared to the main feeder (MF). Its maximum concentrations of 21.26 and $20.63 \mu \mathrm{g} \mathrm{l}^{-1}$ were detected at Ponds 4 and 7 respectively, while its minimum value of $14.38 \mu \mathrm{g} \mathrm{I}^{-1}$ was recorded at Pond 1. With regard to the monthly PO4-P values, its concentrations fluctuated between a minimum of $14.38 \mu \mathrm{g} \mathrm{I}^{-1}$ in August and $23.13 \mu \mathrm{g} \mathrm{I}^{-1}$ in April.

\section{Trace metals:}

Trace metal contents recorded at the sediment of fish ponds were much higher than the corresponding values determined at the River Nile (main feeder). The concentrations of trace metals in edible muscle tissue of each species are summarized in table (3). Iron levels in the muscle fish tissues were consistently high at the fish farm in comparison with $\mathrm{Ni}$ and $\mathrm{Mn}$ contents. Levels of iron in the fish farm fishes ranged from 61.19 to $76.12 \mu \mathrm{g} \mathrm{g}^{-1}$, while in River Nile fishes varied from 51.22 to $68.7 \mu \mathrm{g} \mathrm{g}^{-1}$, Ni from 1.56 to $13.32 \mu \mathrm{g} \mathrm{g}^{-1}$ at fish farm and from 1.71 to $14.99 \mathrm{\mu g} \mathrm{g}^{-1}$ at River Nile, Mn from 0.46 to

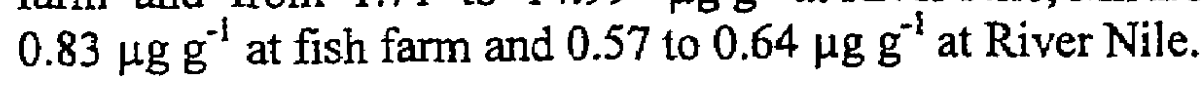




\section{Standing crop and species composition of plankton: \\ Phytoplankton:}

The phytoplankton community was represented by five classes namely: Chlorophyceae, Bacillariophyceae, Cyanophyceae, Dinophyceae and Euglenophyceae (Table 4 and Fig. 1a). Concerning the total phytoplankton crops, their major peak of $624 \mathrm{cell} \times 10^{4} 1^{-1}$ was observed at Pond 1 in July, while the minor one of $34 \times 10^{4} \mathrm{I}^{-1}$ was recorded at Pond 3 in August. With regard to feeders, their numerical density showed two peaks at MF in October $\left(698\right.$ cell $\times 10^{4}$ $\left.\mathrm{I}^{-1}\right)$ and $\mathrm{F} 1$ in April $\left(674\right.$ cell $\left.\times 10^{4} 1^{-1}\right)$ as shown in figures $2 \mathrm{a}$ and $3 \mathrm{a}$.

Chlorophyceae occupied the first predominant position at the ponds and feeders with the exception of MF, where Bacillariophyceae predominated over Chlorophyceae and Cyanophyceae, as shown in table (6). The green algae were dominated by Scenedesmus quadricauda, Tetraedron minimum, Oocystis parva, and Crucigenia quadratc (Fig. 4a).

Bacillariophyceae occupied the second predominant position forming $23.8 \%$ of the total phytoplankton crop. Diatoms occupied $70.4 \%$ of the total phytoplankton crop at MF. Melosira granulata, Synedra ulna and Cyclotella ocellata were the most common diatom species flourished at the ponds (Fig. 5a) and feeders.

Cyanophyceae occupied the third predominant position and constituted $14 \%$ of the total phytoplankton crop at fishponds as shown in table (6). Microcystis and Merismopedia were the most abundant species recorded at the ponds (Fig. 6a) and feeders.

\section{Zooplankton:}

The zooplankton species found in the ponds were all, common in the Nile system especially at Menofi Canal. A total of 52 zooplankton species of which 39 were rotifers, 9 were cladocerans, and 4 were copepods in addition to the other meroplanktonic forms as shown in Table 5 and Figure $1 \mathrm{~b}$. Menofi Canal and Feeder 1 harbored the highest species number ( 33 and 34 respectively), whereas the lowest species number was recorded at Pond 5.

The average zooplankton number in the ponds was 258.4 org $\mathrm{I}^{-1}$, its major peak of 1073 org $\mathrm{I}^{-1}$ was observed at Pond 3 in April, while the minor one of 20 org $l^{-1}$ occurred at Pond 5 in August. With regard to feeders, their numerical density showed two peaks at MF

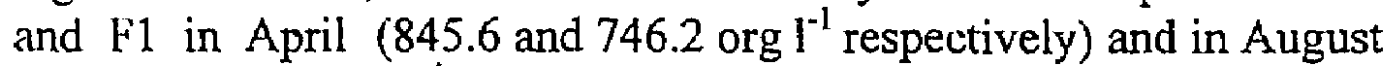

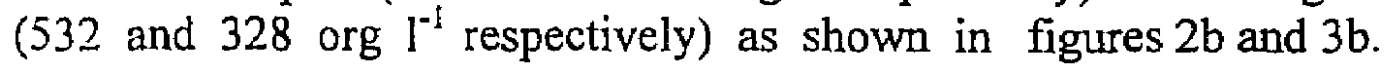
Generally, the maximum count was recorded at Ponds 3 followed by Pond 6. 
RELATIONSHIP BETWEEN PHYTOPLANKTON,

ZOOPLANKTON AND FISH CULTURE IN A FRESHNY ATER

FISH FARM

Rotifers were most common in all ponds. It represented $94.64 \%$ in the ponds and $90.25 \%$ of total zooplankton number in the main feeder (Table 8). Among the thirty-nine species of rotifers found. only few species developed adequate pulses to form sufficient bulk in the samples, whereas the rest of them were found rarely. $B$. condotus, Polyarthra vulgaris, K. cochlearis, and $B$. angularis were the most abundant, while $A$ fissa, $B$. calycillorus, $F$. longiseta, and $T$. pusilli occurred at intermediate densities (Fig. 4b).

The maxinum number of the total rotifers was recorded in MF, F 1 and F 2 during April; while in the fish farm, the maximum number was observed at $P$ onds 3.6, and 7. The highest number of $B$. candalies was recorded in Fl during October, Pond 3 during August. and Pond 6 during July. $K$ cochlearis was domimated in MF. followed by Pond 3 during April. For $B$. angularis, the maximum number was observed in $F 1$ and $F 2$ followed by Pond 3 .

Copepuds belonged to the Canilies Cyclopoidae. Calanoidae, and Harpacticoidae. They were the second most common group among the metazoan zooplankion and constituted $4.23 \%$ of total zooplankton number at the fishponds. Four species were recorded. the adult and copepodite stages were not abundant, while their nauplius lanae were the most dominant stage (Fig. Sb). The maxinum number of nauplius larvae was recorded in the fishponds where they represented $93.99 \%$ of total copepod numbers and $75.16 \%$ in the main feeder as in table 7. The highest numbers of nauplius larvae were recorded at $F 2$ during April, and at Pond 2 during June.

Cladocera was dominated by Moina micrura. The maximum number of total cladoceran organisms was observed at F1, Ponds 1,3, 6. and 7 witls a peak during April. M. micrura constituted $76.50 \%$ of total cladoceran numbers in the fishponds (Fig. 6b). It was dominated during April with maximum number in the last two ponds.

Meroplankton groups were mostly concentrated in Pond 7 and were represented mainly by insect larvae that flourished during April and October.

\section{DISCUSSION}

Phytoplankton and zooplankton communities in fishponds are subjected to wide variations in environmental conditions in addition to the fish predation. The phytoplankton and zooplankton 
communities developed in rearing ponds are influenced by interactions between temperature, water quality, nutrient availability, and fish predation (Lynch and Shapiro, 1981).

Water temperature plays an important role in the activity of aquatic organisms (Reynolds, 1980). It ranged between $23.4^{\circ} \mathrm{C}$ in October and $37.2^{\circ} \mathrm{C}$ in August. The average values of water temperature were correlated negatively with Cladocera $(r=-0.78)$. Khalifa (2000) indicated that there was an inversely proportional highly significant relation between zooplankton community and its water temperature in the River Nile $(r=-0.75)$. The minimum $\mathrm{pH}$ values were recorded at pond 5 followed by a distinct increase at pond 6 . This observation complies quite well with the fluctuation of phytoplankton especially of green and blue-green algae $(\mathrm{r}=0.53 \&$ 0.72 respectively). The monthly $\mathrm{pH}$ values showed a sharp decline in July, while its maximum value was recorded in April.This fluctuation followed the monthly variations of phytoplankton and zooplankton crops, where their numerical density showed an obvious increase in April and had a remarkable decrease in late summer. This finding clearly illustrates that primary producers play an important role in $\mathrm{pH}$ variations at fish farms. These results coincide with of Njoku (1989) and Sweilum (2001) conclusions. Generally, the $\mathrm{pH}$ values of the fish farm under investigation were suitable for fish production except mid summer, when pH values were below 6.5 at most fish ponds. In this connection, Stumm and Morgan (1981) reported that $\mathrm{pH}$ values below 4 and above 11 are lethal for most fish. In the same time, Boyd (1979) stated that the values of $\mathrm{pH}$ ranging between 6.5 to 9 are most suitable for fish production.

. Ammonium concentrations at fishponds were much higher thin the corresponding values of $\mathrm{NO}_{2}-\mathrm{N}$ and $\mathrm{NO}_{3}-\mathrm{N}$. This phenomenon can be related to natural degeneration of nitrogenous organic material of microorganisms yielding ammonia. Fish excretion and decomposition of excess un-consumed feed represented another ammonium sources in ponds (Meade, 1985). Ammonium ions exist at lower $\mathrm{pH}$ values, while the more toxic ammonia is present in more alkaline ( $\mathrm{pH}>9$ ) conditions (EIlis, 1989).

$\mathrm{PO}_{4}-\mathrm{P}$ levels recorded at fishponds showed a remarkable increase compared to the main feeder (MF). This finding could be due to feeding and fertilization of the fish farm during the farming periods. Decomposition of dead organisms represented another source of phosphorus to the aquatic ecosystem (Golachowska, 1986). Stickney et al. (1979) reported that fish release sizable amounts of 


\section{RELATIONSHTP BETWEEN PHYTOPLANKTON, ZOOPLANKTON AND FISH CULTURE IN A FRESHWATER FISH FARM}

phosphate to water and the rejected phosphorus content sometimes represents from 61 to $87 \%$ of the feed phosphorus. They also stated that when the fish is healthy, a large proportion of phosphorus in the faces is orthophosphate

Iron concentrations were substantially high in edible muscle tissues of the fish caught from the fish farm compared to River Nile specimens. Tilapia species feed mostly on detritus, algae and zooplankton that well flourished at the fishponds. Decomposition of these organisms leads to concentration of these metals on the upper sediment layer of the fishponds, and leaches the metals in the next farming season. Konsowa (2001) stated that the accumulation of metallic ions in the flesh of $O$. niloticus is mainly through their natural food of phytoplankton and zooplankton. In the meantime, Iron levels at the selected species were much higher than the corresponding values of $\mathrm{Ni}$ and $\mathrm{Mn}$. This is mainly due to the high concentrations of $\mathrm{Fe}$ in River Nile water. In this connection, I-lassan (1996) and Sobhy (1999) reported that River Nile water contains high levels of metallic ions, especially $\mathrm{Fe}$ which represents the main component of trace metals followed by $\mathrm{Zn}, \mathrm{Cu}, \mathrm{Pb}, \mathrm{Ni}, \mathrm{Hg}, \mathrm{Co}, \mathrm{Cd}$, and $\mathrm{Mn}$.

The phytoplankton densities in the present fishponds were correlated with the densities of zooplankton in the same ponds $(r=0.59)$ as in figure 7. This may be due to two main factors: the regeneration of the nutrients by zooplankton leads to increase the abundance of phytoplankton (Janik, 1989), and the predation of the fishes on large zooplankton leads to the development of phytoplankton (Elhigzi et al. 1995).

Planktivorous fish are known to be size-selective predators that prey selectively on largest zooplankton (Zaret, 1980). The present data are concurrent with this observation since the small rotifers and the nauplius larvae of copepods were the most dominant in fishponds. Microzooplankton (rotifers, nauplius larvae, ciliates, and heterotrophic flagellates) develops better when predatory pressure by zooplankton crustaceans is reduced (Richardson et al., 1990). Carpenter and Kitchell (1993) and Brett \& Goldman (1996) found that removing large and more conspicuous zooplankton, lefts back small crustaceans and small rotifers. Diana et al. (1991) tested the trophic cascade hypothesis in aquaculture ponds containing tilapia at different densities. They detected that fish predations affect not 
only the prey, but also lower trophic levels. They found that zooplankton densities, particularly small zooplankton were reduced in ponds without fish. In a hypertrophic Florida Lake, Beaver et al.(1994) found that the abundance of zooplankters increased dramatically following fish removal (from 22 organisms $\mathrm{I}^{-1}$ in the presence of fishes to 151 organisms $1^{-1}$ after fish removal). In the present study, the average number of zooplankton organisms in April (before stocking of fishes) was 2304 organisms/I while they were 706 organisms/] after fish stocking. For phytoplankton, the average number before fish stocking was $318 \times 10^{4}$-cell ${ }^{-1}$, while it was $231 \mathrm{x}$ $10^{4}$ cell $l^{-1}$ after fish stocking.

Numerical density of phytoplankton implies that green algae occupied the first predominant position at fishponds, while diatoms were the dominant species of River Nile water (MF). Diatoms can be lost by sedimentation from the lentic water of the fish farm ponds, where sedimentation is affected by species composition. This result is confirmed by Meffert (1989) who stated that the blasted silica wall of diatoms would always have the positive advantage of sinking. In the meantime, planktivorous fish reduce the density of large sized algae. In this connection, Sondergaard et al. (1990) found that the removal of about $50 \%$ of planktivorous fish was found to alter the plankton community towards an increase in large-sized diatoms in Lake Sobygird, Denmark. These data are consistent with conciusion of Touliabah (1992) that Chlorophyceae always occupied first dominant position, constituting $65 \%$ of total phytoplankton crop in Serow Fish Farm (South Western shore of Lake Manzalah). Elhigzi et al. (1995) recorded in their experiment with Nile tilapia that the Bacillariophyta dominated in the fishless ponds, while in presence of the Nile tilapia, green algae replaced diatoms. In the same time, Sobhy (1999) reported that diatoms contributed about $55.4 \%$ while green algae constituted $25 \%$ of the total phytoplankton crop at River Nile.

The Nile tilapia appeared to affect the pond ecosystem in monoculture (pond 4) This result agrees with these of Haider (1993). The present results cleared that the highest growth rate of Nile tilapia was in polyculture system than the mono and di-culture (Sweilum, 2001). This may be due to lack of competition for supplementary or natural food between the reared fishes in polyculture. The mixing stocks of tilapia with Clarias usually results in greater fish production in ponds (Gryierek, 1973). For the different phytoplankton and zooplankton groups, no obvius effect was observed in mono, di, and polyculture ponds. 


\section{RELATIONSHIP BETWEEN PHYTOPLANKTON, ZOOPLANKTON AND FISH CULTURE IN A FRESHWATER FISH FARM}

The greater production of fish yield is not only the result of the utilization of food as yet unused components, but is also the result of processes leading to greater productivity of the water body. These processes should be reflected by changes in the phytoplankton and zooplankton as the basic food component of most fishes (Ciborowska, 1972). Balarin and Haller (1983) pointed out that fish production could be increased in presence of natural feeding without adding artificial feeds.

Elhigzi (1995) believed that, Nile tilapia has two different feeding models:(1) size-selective predation, similar to most planktivorous fish species, and (2) a non-selective filter feeding on smaller items like phytoplankton and small zooplankton.

Panov et al (1973) calculated the number of zooplankton organisms in carp rearing ponds, and found that $1.5 \mathrm{org} \mathrm{ml}^{-1}$ must be in the carp rearing ponds. Houde (1973) and Geiger (1983a and b) evaluated that higher concentration of zooplankton organisms may be required if they consist largely of rotifers. Mageed (1996) calculated zooplankton in ponds of tilapia and mugil at El Fayoum fish farms as

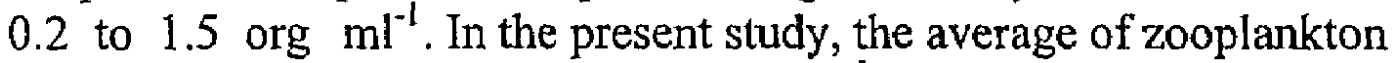
organisms ranged between 0.58 org $\mathrm{ml}^{-1}$ at pond 3 to only 0.13 org $\mathrm{ml}^{-1}$ at pond 5 . This means that the secondary production in the fishponds was poor and insufficient to the high fish production.

All freshwater fishes feed on plankton in a broad sense at some stages of their life. It is generally accepted that the first food of the post - larval fish (after disappearence of the Yolk Sac) consists at least partially of plankton (Fernando, 1994). Mavuti (1990) studied the feeding habits of fish fry and found that they feed mainly on zooplankton (60\%), Chirnomid larvae $(30 \%)$, and algae $(10 \%)$. The fry select larger species as their age and mouth size increase. The contribution of algae increased to more than $50 \%$ for the tilapias as the fry increase in size.

In conclusion, $\mathrm{pH}$ values dropped to a lesser value during July (below 6.5) at most fish ponds. High temperature and low $\mathrm{pH}$ leads to stress on fish life. The fishpond water should be changed during this period or buffering $\mathrm{pH}$ values by liming. The total crop of zooplankton in most fish ponds was not adequate to the high fish production. So, fertilization of ponds should be adjusted to decrease the dependance on the artificial food. The concentration of $\mathrm{Fe}$ in the flesh of the fish farm fishes was much highr than the River Nile fishes 
which may be due to its accumulation in the upper sediment layer of the ponds. So, this layer should be replaced at the end of each farming season.

\section{REFERENCES}

APHA, AWUA, and WPCF. (1992). Standard methods for the examination of water and wastewater. $18^{\text {th }}$. Washington, D.C. $2005 \mathrm{pp}$.

Balarin, J. D. and D. Haller. (1983). Commercial tank culture of tilapia. Proc. Int. 1 Symp. Tilapia. Tiberias, Israel. 473-484.

Beaver, J. R. ; Godwin, W. F. and Crisman, T. L. (1994). Impact of fish removal on the zooplankton community of a hypertrophic Florida Lake. Lake-Reserv.-Manage. 9(2): $55 \mathrm{pp}$.

Booth, R. L. and Lobring, L. B. (1973). Evaluation of the auto analyzer 11-A. Progress report. In advanced in automated analysis: 1972 Technique on International Congress. 8: $7 \mathrm{pp}$. Mediad Inc.

Bornes, H. and Folkard, A. R. (1975). The determination of nitrite. Analysis, 96: 599pp.

Boyd, C. E. (1979). Water quality in warmwater fishponds. Auburn Univ. Agricul. Exp. St., Auburn, AL. 359pp.

Brett, M. T. and Goldman, C. R. (1996). A meta-analysis of the freshwater trophic cascade. Proc. Acad. Sci. USA, 93: 7723-7726

Carpenter, S. R. ; Kitchell, J. F. and Hodgson, J. R. (1985). Cascading trophic interactions and lake productivity. Bio Science 35: 634-639.

Carpenter, S. R. and Kitchell, (eds), (1993). The trophic cascade in lakes. Cambridge studies in ecology. Cambridge University Press, 358pp.Lazzaro, X., 1987. A review of planktivorous fishes: their evolution, feeding behavior, selectivities, and impacts. Hydrobiologia, 146: 97-167. 


\section{RELATIONSHIP BETWEEN PHYTOPLANKTON, ZOOPLANKTON AND FISH CULTURE IN A FRESHWATER FISH FARM}

Ciborowska, (1972). Food of grass carp (Ctenopharyngodon idella Val.), silver carp (Hypophalmichthys molitrix Val.) and big head carp (Aristychthys nobilis Rich.) in polyculture with carp fry. Rocz. Nauk. Roln. Ser. H., 94(2): 41-58.

Diana, J. S. ; Dettweiler, D. J. and Lin, C. K. 1991. Effect of Nile tilapia (Oreochromis niloticus) on the ecosystem of aquaculture ponds, and its significance to the trophic cascade hyphothesis. Can. J. Fish. Aquat. Sci., 48: 183-190.

Dillard, G. E. (1989). Freshwater Algae of the Southestern United States. Western Kentucky Univ. USA, 201 PP.

Edmandson, W. T. (1966). Freshwater biology (211 ed.), New York, London, John Wiely \& Sons, Inc, 74 pp.

Fernando, C. H. (1994). Zooplankton, fish and fisheries in tropical freshwater. Hydrobiologia, 272: 105-123.

Elhigzi, F. A. R. ; Haider, S. A. and Larsson, P. (1995). Interactions between Nile tilapia (Oreochromis niloticus) and cladocerans in ponds (Khartoum, Sudan). Hydrobiologia, 307: 263-272.

Ellis, K. V. (1989). Surface water pollution and its control. Env. Heal. Eng. Univ., 366pp.

Golachowska, J. (1986). Diurnal fluctuation of phosphorus forms in lake water and seston. Pol. Arch. Hydrobiol, 33: 165-175.

Grygierek, E. (1973). The influence of phytophagous fish on pond zooplankton. Aquacult., 2: 197-208.

Haider, S. A. (1993). Pond experiments with omnivorous fish Nile tilapia (Oreochromis niloticus); Effect of succession of phytoplankton and Cladocera populations. Thesis, Univ., Bergen, Norway, 54pp. 
Hassan, H. T. (1996). Ecological studies on the Nile River phytoplankton in relation to physico-chemical characteristics at the area between Esna and Delta Barrage. Ph. D. Thesis, Botany Dep., Fac. of Girls, Ain Shams Univ., 203pp.

Hornung, H. and N. Kress. (1991). Trace elements in offshore and inshore fish from Mediterranean Sea. NIO, Haifa, Palestine, 31: 135-145.

Houde, E. D. (1973). Some recent advances and unsolved problems in the culture of marine fish larvae. Proc. World Maricult. Soc., 3: 83-112.

Ishak, M. M. ; Sayes, A. and Tallaat, K. (1985). Tilapia fisheries in Lake Borollus (Egypt). Kuwait. Bull. Mar. Sci., 6: 225-242.

Janik, J. J. (1989). Nutrient recycling in Castle Lake, California: Phytoplankton-zooplankton interactions. Diss. ABST. INT. - PT. -B. - and - ENG. 49 (8): 141pp.

Khalifa, N. S. (2000). Study on the impact of industrial wastes at Helwan on River Nile zooplankton. Ph.D. Thesis, Cairo Univ., 165pp.

Kimor, B. and Pollingher, U. (1965). The plankton algae of Lake Tiberias. Ministry of agriculture, Dep. Of Fisheries. Sea Fisheries Res. Stat., Haifa, 76 pp.

Konsowa, A. H. (2001). Impacts of trace metals on the distribution of phytoplankton and their content in Oreochromis niloticus at Rosetta Branch. Egy.J. Aquat. Biol. \& Fish., 5(4):237-249.

Lynch, M. and Shapiro, J. (1981). Predation, enrichement, and phytoplankton community structure. Limnol. Oceanogr., 26 (1): 86-102.

Mageed, A. A. (1996). Zooplankton assemblages and their role as natural food for the cultivated fishes in El Fayoum fish farms-Egypt. Bull. Fac. Sci., Zagazig Univ., 18 (2): 330341. 


\section{RELATIONSHIP BETWEEN PHYTOPLANKTON, ZOOPLANKTON AND FISH CULTURE IN A FRESHWATER FISH FARM}

Mavuti, K. M. (1990). Ecology and role of zooplankton in the fishery of Lake Naivasha, Hydrobiologia, 208: 131-140.

Meade, J. W. (1985). Allowable ammonia for fish culture. Prog. FishCult., 47:135-145.

Meffert. M. E. (1989). Planktonic unsheathed filaments (Cyanophyceae) with polar and central gas vacuoles. II. Biology. Population dynamics and biotopes of Limnothrix redekei (Van Goor) Meffert. Arch. Hydrobiol, 116: 257282.

Messiha-Hanna, R. G. (1992). Sequential extraction of metals in Cooks River sediments. Proceeding of bioaccumulation workshop: assessment of distribution, impacts and bioaccumulations in Aquatic enviroments. Water Board and Australian Marine Science Association Inc., Sydney.

Najoku, D. C. (1997). Effect of different manure levels on fish growth, mortality and yield in a horizontally integrated fish-cum. Poultry farming system in Nigeria. Aquaclt. Res., 28: $651-660$.

Nydahi; F. (1976). The optimum conditions for the reduction of nitrate by Cadmium. Talanta, 323-349.

Panov, D. A. ; Chromov, L. V. and Motenkova, L. G. (1973). Forming of the food base of ponds during rearing of phytophagous fish larvae. Biol. Resur. Vodoemov Mold., 11: 115-120 (in Russian).

Pennak, R. W. (1978). Freshwater invertebrates of the United States. $\left(2^{\text {nd }}\right.$ ed). John Wiely and Sons. New York, $803 \mathrm{pp}$

Reynolds, C. S. (1980). Phytoplankton assemblages and their periodicity in stratifying lake system. Holarctic Ecol. 3: 141-159. 
Richardson. W. B. ; Wickham, S. A. and Threlkeld, S. T. (1990). Foodweb response to the experimental manipulation of a bentivore (Cypinus carpio), zooplankton (Menidia heryllina) and benthic insects. Arch. Hydrobiol, 119: 143165.

Ruttner-Kolisko, A. (1974). Planktonic rotifers. Biology and Taxonomy. Binnengewasser - Supply., 26: 146pp.

Sarvala, J. ; Helminen, H. ; Saarikari, V. ; Salonen, S. and Vuorio, K. (1998). Relations between planktivorous fish abundance, zooplankton and phytoplankton in three lakes of differing productivity. Hydrobiologia, 363: 81-95.

Shehata, T. M. ; Shehata, M. B. and Taha, O. E. (1994). Studies of the effect of different diets on fish performance and the water quality changes in fertilized fishponds. New Egypt. J. Med., 11 (3): 1105-1112.

Sobhy, E. H. M. (1999). Effects of industrial waste of Iron and Steel Factories on Nile phytoplankton communities and productivity at Helwan. M. Sc., Fac. Sci., Men. Univ., 231pp.

Sondergaard, M. ; Jeppesen, E. ; Kristensen, P. and Sortkjaer, O. (1990). Interaction between sediment and water in shallow and hypertrophic lake: a study on phytoplankton collapses in lake Sobygard. Denmark. Hydrobiologia, 191: 129-138.

Stansbery, D. H. (1971). The distribution of algae by Division, Classes and Order. Ohio state Univ.,181 pp.

Stickney, R. R. ; Hesby, J. H. and Isbell, W. A. (1979). Growth of Tilapia nilotica in ponds with different histories of fertilization. Aquacult., 17: 189-194.

Strickland, J. D. H. and Parsons, T. R. (1965). A manual of sea water analysis. $2^{\text {nd }}$ Edition. Fisheries Research Board of Canada Ottawa. 287pp. 


\section{RELATIONSHIP BETWEEN PHYTOPLANKTON, ZOOPLANKTON AND FISH CULTURE IN A FRESHWATER FISH FARM}

Stumm. W. and Morgan, J. J. (1981). Aquatic chemistry. An introduction emphasizing chemical equilibria in natural waters. $2^{\text {nd }}$ Ed. John Wiley and Sons. NY., 780pp.

Sweilum, M. A. (2001). Growth performance and production of Oreochromis niloticus using polyculture systems and fertilizers. Egypt. J. Aquat. Biol. \& Fish., 5 (2): 105-119.

Touliabah, H. S. (1992). Relations between fertilization and phytoplankton composition and productivity in Serw Fish Farm. M.Sc., Girl Coll. Ain Shams Univ. 213pp.

Verheye, H. M. and Dumont, H. J. (1984). The calanoid copepods of the Nile system, Hydrobiologia, J10: 191-212.

Vinyard, W. C. (1975). A Key to the genera marine planktonic diatoms of the Pacific coast of North America, $26 \mathrm{pp}$.

Weber, C. I. (1971). A guide to the common diatoms at water pollution surveillance system. Analytical quality control, Cincinnati, Ohio, $78 \mathrm{pp}$.

Yamamato, K. (1960). Plankton rotation Japanese Inland. Hyd. Vol.XVI 4: 364-411.

Zaret, T. M. (1980). Predation and freshwater communities. New Haven and London, Yale Univ. Press, 187pp. 
Table (l): Area $\left(\mathrm{m}^{2}\right)$, stocking density (fish/pond), and and stocking rates

\begin{tabular}{|c|c|c|c|c|c|c|}
\hline & Area & & Stocking d & & & Stocking \\
\hline & $\mathbf{m}^{2}$ & O. niloticus & T. galilios & C. gariepinus & $\left(4 F i s h / m^{2}\right)$ & Rates \\
\hline Pond 1 & 450 & 900 & 900 & * & 1800 & $1^{* 1 * 0}$ \\
\hline Pond 2 & 900 & 1800 & 1200 & 600 & 3600 & $3 * 2 * 1$ \\
\hline Pond 3 & 1200 & 2400 & 1600 & 800 & 4800 & $3 * 2 * 1$ \\
\hline Pond 4 & 300 & 1200 & 4 & $*$ & 1200 & $1^{*} 0^{*} 0$ \\
\hline Pond 5 & 750 & 2250 & * & 750 & 3000 & $3 * 0 * 1$ \\
\hline Pond 6 & 800 & 2400 & * & 800 & 3200 & $3 * 0 * 1$ \\
\hline Pond 7 & 525 & 1050 & 1050 & * & 2100 & $1 * 1 * 0$ \\
\hline
\end{tabular}

Table (2): Average values of temperature ${ }^{0} \mathrm{C}, \mathrm{pH}$, nitrite $(\mu \mathrm{g} / \mathrm{l})$, nitrate $(\mu \mathrm{g} / \mathrm{l})$, ammonium $(\mu \mathrm{g} / \mathrm{l})$ and phosphate $(\mu \mathrm{g} / \mathrm{l})$.

\begin{tabular}{|c|c|c|c|c|c|c|c|c|c|c|}
\hline & \multicolumn{3}{|c|}{ Tamperature $\left({ }^{\circ} \mathrm{C}\right)$} & \multicolumn{3}{|c|}{ PH } & \multicolumn{3}{|c|}{ Avg. Nitrogen compounds } & \multirow{2}{*}{$\frac{\text { Avg. }}{\mathrm{PO}_{4} \mu \mathrm{g} /}$} \\
\hline & Min. & Max. & Avg. & Min. & Max. & Avg. & $\mathrm{NO}_{2 \mu / 1}$ & $\mathrm{NO}_{3 \mu \mathrm{g} / \mathrm{I}}$ & $\mathrm{NH}_{4} \mu \mathrm{g} /$ & \\
\hline Main Feeder & 23.7 & 31.7 & 28.7 & 6.53 & 8.27 & 7.56 & 8.03 & 83.2 & 277.44 & 11.25 \\
\hline Feeder I & 24.2 & 33.5 & 30.2 & 6.58 & 8.44 & 7.75 & 6.8 & 233.6 & 750.71 & 11.88 \\
\hline Fider 2 & 24.7 & 34.1 & 30.7 & 6.19 & 8.23 & 7.35 & 9.27 & 150.4 & 479.4 & 22.6 \\
\hline Pond 1 & 24.6 & 37.2 & 31.5 & 6.38 & 8.29 & 7.7 & 25.34 & 62.4 & 227.8 & 14.38 \\
\hline Pond 2 & 23.5 & 36.6 & 31.5 & 6.85 & 8.4 & 7.92 & 10.82 & 52.8 & 222.36 & 16.25 \\
\hline Pond 3 & 23.8 & 35.7 & 31.1 & 6.53 & 8.38 & 7.76 & 6.8 & 219.2 & 595 & 15 \\
\hline Pond 4 & 23.4 & 34.5 & 30.3 & 6.82 & 8.71 & 7.81 & 6.18 & 169.6 & 414.8 & 21.26 \\
\hline Pond 5 & 23.7 & 33.3 & 30 & 6.35 & 8.36 & 7.61 & 7.42 & 161.6 & 717.4 & 18.75 \\
\hline Pond 6 & 23.8 & 33.2 & 29.4 & 7.63 & 8.29 & 8.03 & 17.3 & 60.8 & 274.72 & 18.75 \\
\hline Pond 7 & 23.8 & 30.9 & 28.3 & 6.03 & 8.31 & 7.39 & 19.16 & 67.2 & 179.52 & 20.63 \\
\hline
\end{tabular}

Table (3): Trace metal concentrations in muscle tissues of Oreochromis niloticus, Tharothrodon galilios, and Tilapia zillii ( $\mu \mathrm{g} / \mathrm{g}$ wet wt.) and sediment of the Barrage Fish Farm and River Nile

\begin{tabular}{|c|c|c|c|c|c|c|c|c|c|}
\hline \multirow[b]{2}{*}{ Sites } & \multicolumn{6}{|c|}{ Fishes $\mu \mathrm{g} / \mathrm{g}$} & \multicolumn{3}{|c|}{ Sediment $\mu \mathrm{g} / \mathrm{g}$} \\
\hline & Spectes & Specodinemene. no. & Stuor rmoo (mm) & $\mathrm{Fe}$ & $M n$ & $\mathrm{Ni}$ & $\mathrm{Fe}$ & $\overline{M n}$ & $\mathrm{Ni}$ \\
\hline Fish Farm & $\begin{array}{l}\text { O.nublious } \\
\text { S.gallibs }\end{array}$ & $\begin{array}{c}10 \\
B \\
8\end{array}$ & $\begin{array}{l}110-150 \\
120-150 \\
05-110\end{array}$ & $\begin{array}{l}72.06 \\
76.12 \\
61.10\end{array}$ & $\begin{array}{c}13.32 \\
1.56 \\
254\end{array}$ & $\begin{array}{l}0.83 \\
0.83 \\
0.46\end{array}$ & 840 & 310 & 15 \\
\hline River Nile & 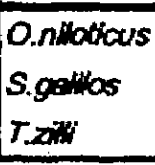 & $\begin{array}{l}8 \\
6 \\
7\end{array}$ & $\begin{array}{l}100-140 \\
105-140 \\
100-110\end{array}$ & $\begin{array}{c}64.52 \\
68.7 \\
51.22\end{array}$ & $\begin{array}{l}14.99 \\
1.71 \\
1.89\end{array}$ & $\begin{array}{l}\overline{0.64} \\
0.57 \\
0.62\end{array}$ & 710 & 242 & 10 \\
\hline
\end{tabular}




\section{RELATIONSHIP BETWEEN PHYTOPLANKTON, ZOOPLANKTON AND FISH CULTURE IN A FRESHWATER FISH FARM}

Table (4): List of the recorded phytoplankton species at MF, F $1 \&$ F 2 and the fishponds.

\begin{tabular}{|c|c|c|c|}
\hline \multicolumn{4}{|c|}{ PHYTOPLANKTON } \\
\hline Chlorophyceae:- & & Melosira gramulata & (Her.) Ralfs \\
\hline Scenedesmus quadricauda & (Turpin) Brebisson & M,granulata var.angustissma & Muller \\
\hline S. bicaudatus & Chodat & Nitschia palea & (Kutz.)W.Smith \\
\hline Oocystis parva & W.et. G.S.West & N. clasterium & W.Smith \\
\hline O. solitaria & Wittrock & N. gracilis & Hantz \\
\hline 0. gigas & Archer & Syntedro udna & (Niyz.)Her \\
\hline Pediastrum simplex & Meyen & S. ulna var. biceps & (Kutz) \\
\hline P. simplex var.siurmii & (Reinsch) Wolle & S. ulna var. danica & (Kutz.) Grun) \\
\hline p. clathratum & (Schyoeter)Lemmer & Pleurosigma elongatum & W.Smith \\
\hline P. duplex & Meyen & Amphora ovalis & Kutz \\
\hline Lagerheimia ciliata & (Lageneim)Chodat & Rhopalodia gibberula & (Her.)O.F.Muller \\
\hline L. ciriformis & (Snow)Collins & Cyanophyceae:- & \\
\hline Kirchneriella obesa & (West)Schmidle & Microcystis aeruginosa & Kutz \\
\hline Golenkinia radiata & (Chodat)Wille. & M. flos-aquae & (Witter.)Elenkin \\
\hline G. pancispina & West \& West & Gomphosphaeria aponiana & Kutz \\
\hline Coelastrumsp. & & Merismopedia tenuissima & Lemmer. \\
\hline Dictyosphaerium pulchellum & Wood & M. punctata & Meyen \\
\hline D. subsolitaritum & $\operatorname{Van}$ Goor & Chroococcus turgidus & (Kutz)Nageli \\
\hline Tetraedron minimum & (A.Braun)Hansgirg & Cylindrospermopsis raciborskil & iit Wolosz \\
\hline T. trigomum & (Naegeli)Hansgirg & Phormidium tentce & (M enegh.) \\
\hline Strourastrum natator & W.West & Lyngbya limnetica & Lemmer. \\
\hline S. gracile & Ralfs & Spirulina major & Kutz \\
\hline Crucigenia quatralo & Morren & Dinophyceae:- & \\
\hline C. rectangtularia & (A.Br.) Gay & Peridinium cinctum & (O.F.Mullex) \\
\hline Chlorella vulgaris & Beijerinck & Phacus pleuronectes & (O.F.Muller)Dujardin \\
\hline $\begin{array}{l}\text { Bacillariophyceae:- } \\
\text { Cyclotella acellata }\end{array}$ & Pant & $\begin{array}{l}\text { Euglenophyceae:- } \\
\text { Euglena acus }\end{array}$ & Her. \\
\hline C. operculata & Kutz & Euglena varibilis & Klebs. \\
\hline C. glomerata & Bachmann & & \\
\hline
\end{tabular}


Table (5): List of the recorded zooplankton species at MF, F 1\& F 2 and the fishponds.

\begin{tabular}{|c|c|c|c|}
\hline 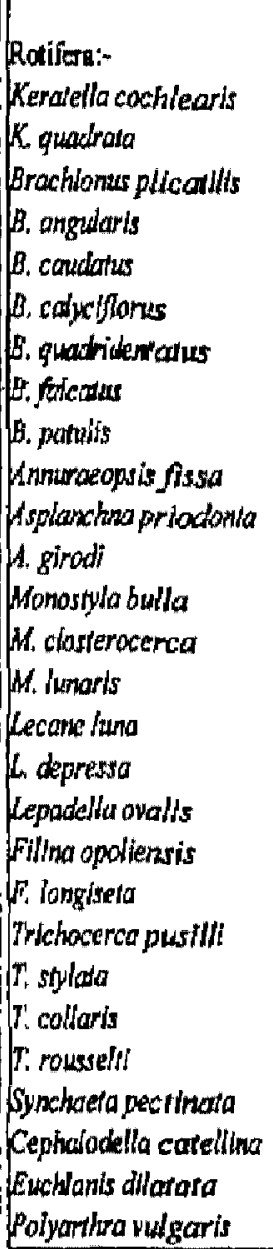 & 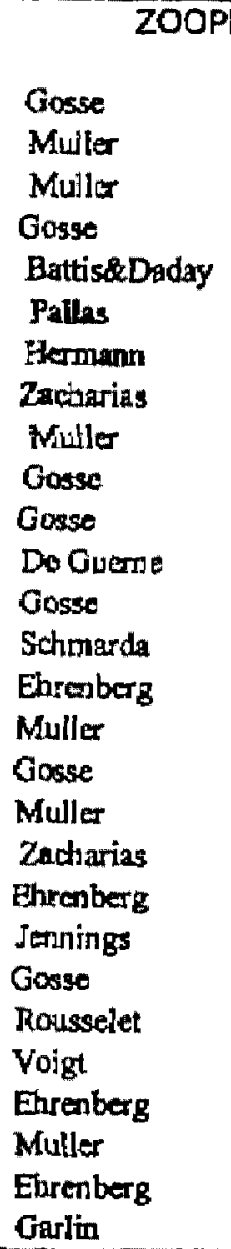 & 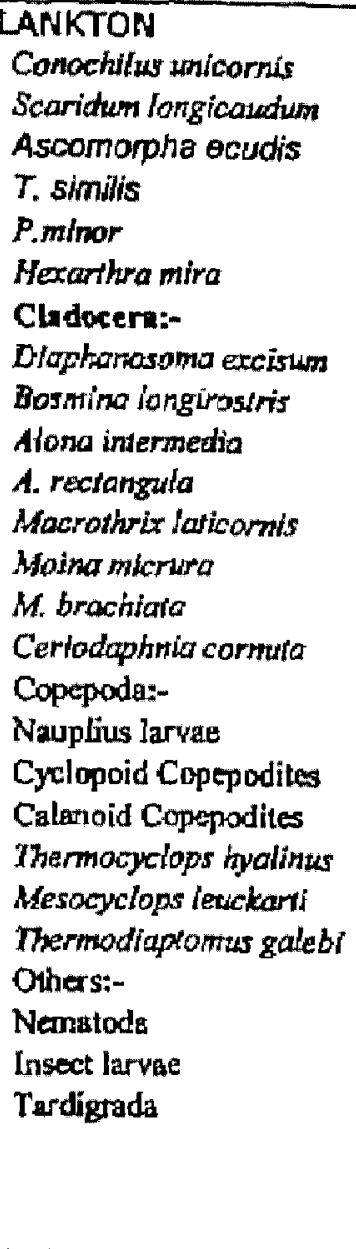 & $\begin{array}{l}\text { Roussle! } \\
\text { Muller } \\
\text { Perty } \\
\text { Wierzejsik: } \\
\text { Voigt } \\
\text { Hudion } \\
\text { Sars } \\
\text { Muller } \\
\text { Sars } \\
\text { Surs } \\
\text { Jurine } \\
\text { Luat } \\
\text { Jurine } \\
\text { Sars }\end{array}$ \\
\hline
\end{tabular}

Tubie (6): Distribution of the main groups of the plarikton at the fishponds

\begin{tabular}{|c|c|c|c|c|c|c|c|}
\hline Stations & Pond 1 & Pond 2 & Pond 3 & Pond 4 & Pond 5 & Pond 6 & Pond 7 \\
\hline 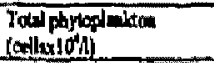 & 292 & 194 & 299 & 260 & 139 & 356 & 196 \\
\hline Chlorophycese & 116 & 132 & 163 & 144 & 80 & 256 & 155 \\
\hline Bacillariophyoese & 123 & 39 & 74 & 49 & 38 & 56 & 36 \\
\hline Cyanophyceac & 13 & 22 & 18 & 59 & 21 & 62 & 4.2 \\
\hline Others & 30 & 0 & 30 & 84 & 0 & 0 & 0.0 \\
\hline Znopiankion (arg/) & 150.7 & 234.4 & 580 & 155.6 & 133.2 & 301.3 & 232.5 \\
\hline Rotiess & 1320 & 182.1 & 549.5 & 149.9 & 120.8 & 275.9 & 205.6 \\
\hline Cladooern & 3.4 & 1.7 & 4 & $\ldots 0.75$ & $0.93 \ldots$ & 8.7 & .162 \\
\hline Copepoda & 9.5 & 50.9 & 25.7 & 4.7 & 11.3 & 16.4 & 10.6 \\
\hline Others & 0.33 & 0 & 0.7 & 0.17 & 0 & 0.37 & 0.70 \\
\hline
\end{tabular}




\section{RELATIONSHIP BETWEEN PHYTOPLANKTON, ZOOPLANKTON AND FISH CULTURE IN A FRESHWATER FISH FARM}

Table (7): The percentage abundance of the main groups to the total phytoplankton crop.

\begin{tabular}{|l|c|c|c|c|}
\hline Classes & MF & F1 & F2 & Ponds \\
\hline Chlorophyceae & 13.7 & 53.7 & 57 & 60 \\
\hline Bacillariophyceae & 70.4 & 35.8 & 34 & 25.8 \\
\hline Cyanophyceae & 15.6 & 7.5 & 9 & 14.05 \\
\hline
\end{tabular}

Table (8): The percentage abundance of the main groups to the total Zooplankton crop.

\begin{tabular}{|l|c|c|c|c|}
\hline GROUPS & Main Feeder & Feeder 1 & Feeder 2 & Ponds \\
\hline Rotifera & 90.25 & 91.2 & 84.39 & 94.64 \\
\hline Copepoda: & 5.57 & 6.47 & 14.02 & 4.23 \\
\hline (Nauplii) & $(75.16)$ & $(81.66)$ & $(93)$ & $(93.99)$ \\
\hline Cladocera & 3.33 & 2.69 & 0.87 & 1.01 \\
\hline Others & 0.45 & 0.71 & 0.74 & 0.13 \\
\hline
\end{tabular}

Table (9): Correlation coefficient between the different groups of phytoplankton, zooplankton and some physico-chemical characters.

\begin{tabular}{|c|c|c|c|c|c|c|c|c|c|c|c|}
\hline & $\mathrm{NO}_{2} u g /$ & $\mathrm{NO}_{3}$ ug/ & $\mathrm{NH}_{4}, 4 \mathrm{~g} /$ & $\mathrm{PO}_{4}$ ugl & Temp. & pH & Rotifera & Cludocert & Copepoda & Chloro. & Becillwio. \\
\hline Cyanophyta. & 0.28 & 0.08 & 0.04 & 0.42 & -0.09 & 0.72 & -0.06 & -0.26 & -0.18 & 0.57 & -0.17 \\
\hline Bucilleriophyta. & 0.56 & 0.07 & -0.15 & 0.7 & 0.55 & 0.08 & 0.12 & -0.18 & -0.22 & -0.06 & \\
\hline Chicorophyta & 0.19 & 0.24 & -0.37 & 0.15 & -0.35 & 0.53 & 0.43 & 0.47 & 0.03 & & \\
\hline Copepode & -0.22 & -0.21 & -0.16 & 0.46 & 0.48 & 0.43 & 0.25 & -0.21 & & & \\
\hline Cladocen & 0.53 & -0.43 & -0.52 & 0.33 & -0.78 & 0.45 & 0.13 & & & & \\
\hline Rotifera & -0.28 & 0.50 & 0.27 & 0.38 & 0.12 & 0.17 & & & & & \\
\hline
\end{tabular}




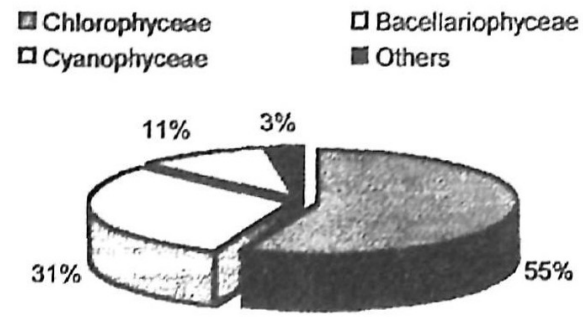

Fig. 1a: Percentage of ocurrence of the different phytoplankton groups

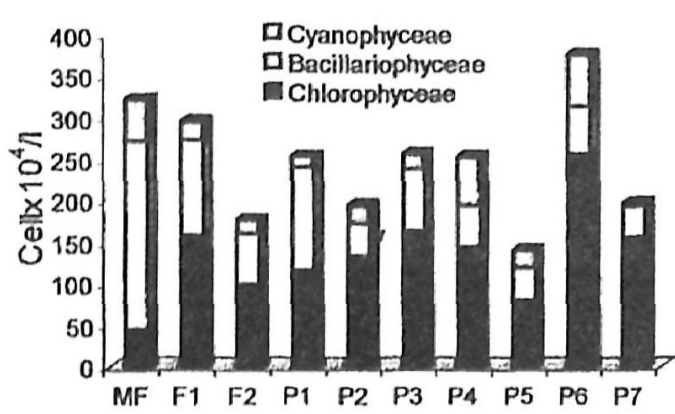

Fig. 2a: Distribution of the main phytoplankton groups.

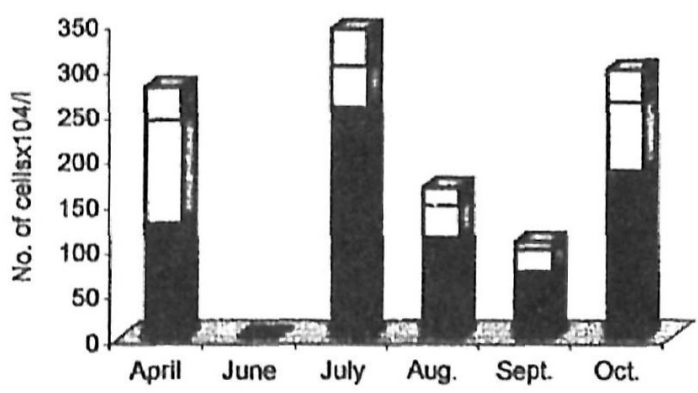

Fig. 3a: Monthly variations of the main phytoplankton groups at the fish ponds

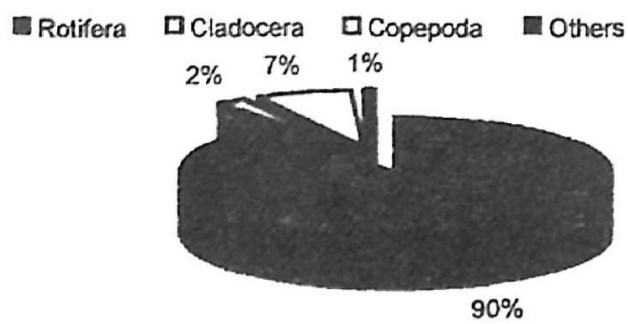

Fig. 1b: Percentage of ocurrence of the different zooplankton groups

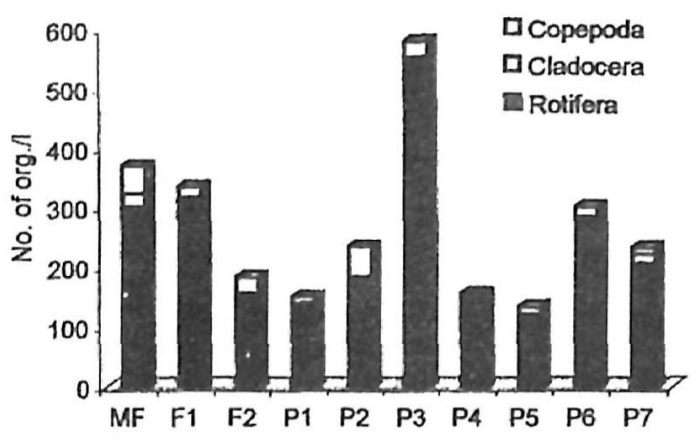

Fig. 2b: Distribution of the main zooplankton groups.

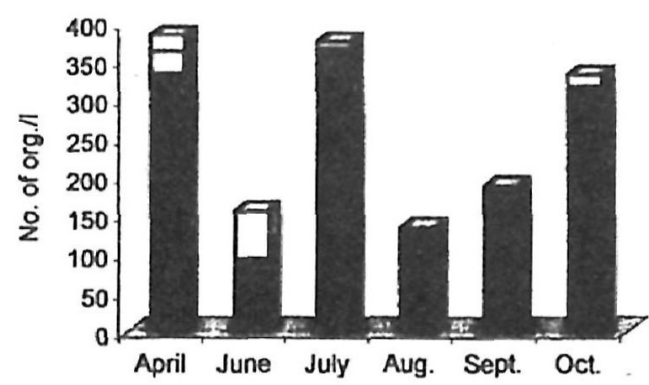

Fig. 3b: Monthly variations of the main zooplankton groups at the fish ponds 


\section{RELATIONSHIP BETWEEN PHYTOPLANKTON,

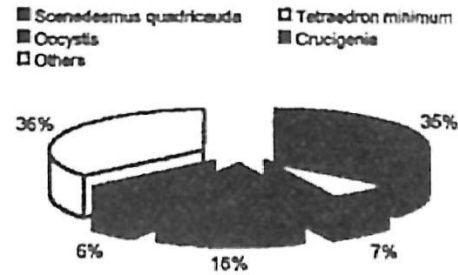

Fig. 4a: Percentage of ocurrence of the dominant Chlorophyceas species 口Moloeiera oranulata $\quad$ ESynedra una 口Cyclotella ocelleta $\quad$ Oonera

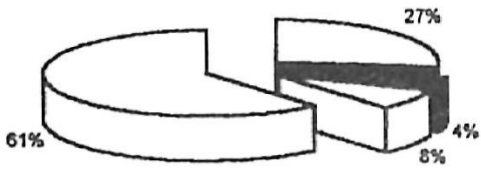

Fig. 5a: Percentage of ocurrence of the dominant Bacellariophyceae species

口Microcystis aMerismopedin wOthers $21 \%$

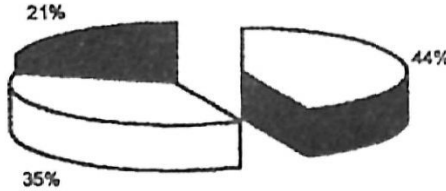

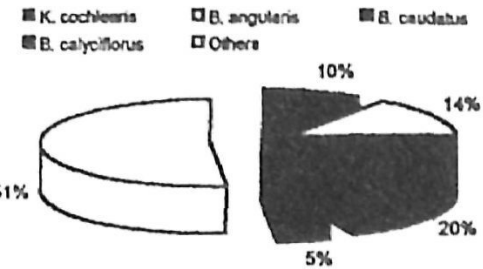

Fig.4b: Percentege of ocurrence of tho dominant rotiferan spocies

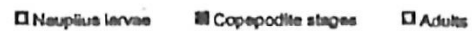

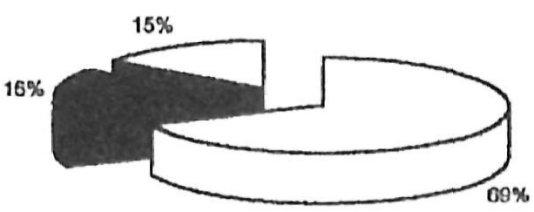

Fig. 5b: Percentage of ocumence of the different copepod stoges

aMoina mlerurn nOthers

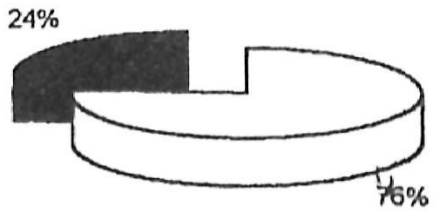

Fig. 6a: Percentage of ocurrence of the dominant Cyanophyceae species

Fig. 6b: Percentage of ocurrence of the donminant Cladoceran species

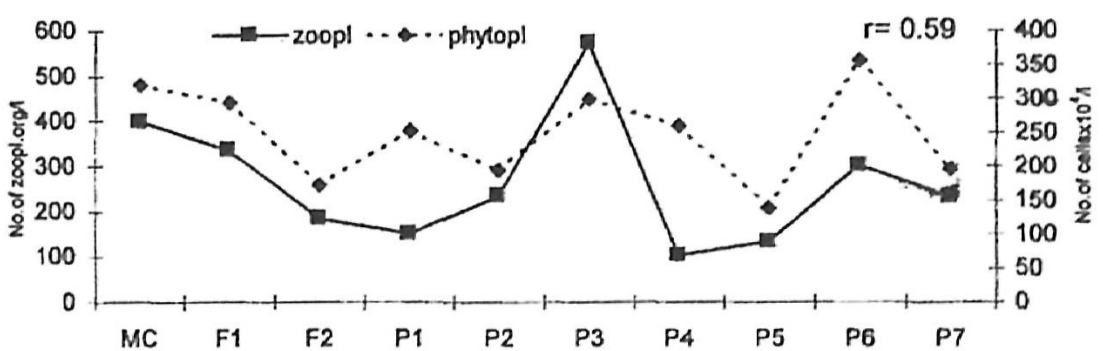

Fig. 7:Relationship between phytoplankton and zooplankton numbers 